https://doi.org/10.18485/cosic_dobrica.2018.ch7

821.163.41.09-94 Ћосић Д.

\author{
МАРКО Ј. НЕДИК* \\ Српска књижевна задруга \\ Београд
}

\title{
НАРАТИВНИ ПОРТРЕТИ САВРЕМЕНИКА У КЊИЗИ ПРИЈАТЕЉИ ДОБРИЦЕ ЋОСИЋА
}

\begin{abstract}
У раду је анализирана књига Добрице Ћосића Пријашељьи, у којој се налазе његови портрети пријатеља и савременика. Уз ту књигу такође су тумачени и његови други мемоарско-есејистички текстови о савременицима у књигама Писии моїа века и Пријайељи моїа века. Уз општу оцену књижевног дела Д. Ћосића и његовог доприноса српској књижевности и култури друге половине 20. и прве деценије 21. века, представљена је генеза његовог животног пута која је била битна за формирање његове стваралачке и јавне личности. У основном делу рада анализиране су кључне поетичке одлике портрета, уз критичку опсервацију да се оне, поред документарног и аутобиографског слоја, и општог тона толеранције коју исказује аутор, налазе у изразитој наративности текстова, као и у сагледавању основних етичких и стваралачких особина описиваних личности.
\end{abstract}

Кључне речи: Д. Ћосић, Пријайељи, генеза животног и стваралачког пута, писци, сликари, књижевни критичари, филозофи, пријатељи из завичаја, наративност портрета, етичка и стваралачка компонента портретисаних личности, толерантност.

Писац који је у српској књижевности, култури и друштвеном животу својим књижевним делом, јавном и политичком активношћу и својом харизматичном личношћу трајно обележио другу половину 20. и прву деценију и по 21. века без сумње је био Добрица Ћосић. Значај његовог књижевног дела и друштвеног ангажовања у првом реду се мора сагледавати у књижевноеволутивном и културолошком контексту, али се ни у таквом виђењу не може занемарити његово непосредно друштвено и политичко значење, јер је књижевни контекст у Ћосићевом случају био нераскидиво везан са друштвеним и политичким и у значајној мери условљен њиме. Доминантно политичка перспектива, међутим, из које су од 1968. године, од времена у којем је „прешао на другу обалу" и одлучно се разишао са званичном партијском политиком, његово књи-

*markone43@gmail.com 
жевно дело и његова личност најчешће процењивани, нанела је не малу штету потпунијем тумачењу и објективнијем вредновању његових романескних остварења и њиховом значају за развој српске културе друге половине претходног века. А тај значај изузетно је велик. Велик је зато што је Ћосић у својим романима дао широко засновану наративну слику српског друштва у целом том веку, какву с таквом обухватношћу није дао ниједан други српски писац ни пре ни после њега. (Њему су, по тематском обухвату у књижевном делу друштвене, културне или историјске ситуације нашег простора, донекле слични Михаило Лалић, Борислав Пекић, Павле Угринов и Живојин Павловић, али са другачијом поетичком функцијом своје прозе и другачијим местом своје јавне личности у друштвеном животу.)

Ћосићево књижевно дело, мотивисано неопходном потребом критичког и аналитичког разумевања кључних узрока настанка, облика појављивања и последица друштвених, идеолошких, културних и других промена, изазова и противуречности на сложеној и драматичној историјској и културној мапи Србије у 20. веку, употпунило је општу слику развоја српског друштва у новијем времену. Те промене и њихове последице, које у нашој средини трају све до данашњих дана, подједнако рефлектоване у политичкој мисли, култури, стваралаштву и непосредној животној пракси, препознате су и на естетски адекватан начин оживљене у целокупном Ћосићевом књижевном, есејистичком, мемоарско-аутобиографском и публицистичком делу. У њему је проблематизована и наративним средствима оптимално остварена изузетно значајна критичка слика развоја српског друштва у 20. веку, који је новијој историји и култури Србије подарио велике националне, демократске, политичке, културне, стваралачке и друге резултате, идеје и узлете, али исто тако и велике падове и промашаје.

Да би потпуније били протумачени Ћосићеви наративни портрети пријатеља с којима је у дужем временском периоду делио исте или сличне ставове о књижевности, култури, друштву, политици, објављени

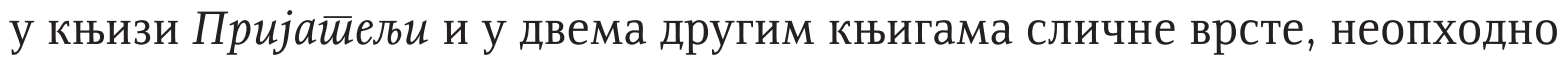
је нагласити неке моменте из његовог живота који су умногоме одређивали његову личност и њене рефлексе у књижевном делу. Први међу њима је тај да је одрастао и да се као личност формирао у сеоској средини, да је рано сагледао предности и недостатке живота у њој, али да је антејски остао везан за свој завичај и живот моравског поднебља и када је напустио завичајни простор. Његово порекло, дакле, умногоме је одредило његову визију живота и стваралаштва. Такође важна чињеница за његову приврженост појединим личностима свога времена јесте његова припадност напредној Комунистичкој омладини Србије и међурат- 
не Југославије формираној пред опасношћу од ширења фашизма пред Други светски рат, као и то да је с пуном идеолошком и хуманистичком свешћу, и с пуно младалачког идеализма, веровао у праведност ослободилачке партизанске борбе претворене у току рата у друштвену револуцију за измену политичког система земље.

Такође се, у сагледавању његове улоге у развоју српског друштва, културе, уметности и књижевности, рефлектоване на његове портрете савременика, посебно мора нагласити чињеница да је он, заједно с пријатељима из раног послератног времена, припадао интелектуалној и стваралачкој групи која се окупљала у Симиној улици број 9а у Београду, првој значајнијој групи младих стваралаца и интелектуалаца који су, макар и вербално и у затвореном кругу оних који су слично мислили о многим стварима уметности и друштва, доводили у сумњу недемократске принципе раног послератног друштвеног и политичког живота у земљи. Исто тако је важна чињеница што је у тој групи „симиноваца", како их је доцније сам назвао, било будућих сликара, писаца, критичара, историчара уметности, филозофа и научника, и да је висок интелектуални ниво њених припадника и те како имао утицаја на ставове о друштву, уметности и књижевности на све њене припаднике, па и на Добрицу Ћосића. Од не мале важности је и време у којем је Ћосић, заједно са Оскаром Давичом, Антонијем Исаковићем, песницима Васком Попом, Миодрагом Павловићем, критичарима Зораном Мишићем, Бориславом Михајловићем Михизом, Петром Џаџићем и бившим надреалистима, припадао првој продуктивној модернистичкој струји српске књижевности после Другог светског рата и да је заједно с појединим некадашњим надреалистима био један од покретача модерно оријентисаног часописа Дело, у којем је потврђивана снага новог израза српске књижевности.

За настанак, садржину и избор личности које ће се наћи у његовим портретима пријатеља посебно је важно што се он изворно залагао за отворене односе у друштву и култури, и што је у таквој активности био доследан од првих година у Симиној 9а, у Удружењу књижевника Србије и његовој трибини у Француској 7, у активностима критички оријентисаног филозофског часописа Праксис, у Српској књижевној задрузи, у Одбору за одбрану слободе мисли и изражавања, чији је био један од оснивача, у акцији око покретања, пре објављивања забрањеног часописа

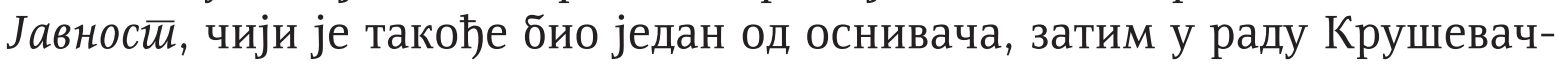
ке Филозофско-књижевне школе, па све до последњих година у активностима Српске академије наука и уметности и у јавном друштвеном и културном животу Београда и Србије. Био је један од најдоследнијих заговорника демократизације српског и југословенског друштва, док је ово друго постојало, и постављања и решавања положаја српског народа 
првенствено као демократског питања. Све те чињенице на један начин су посредно пројектоване у његово романсијерско дело, а на други, непосреднији, у његове записе, дневнике, сећања и портрете пријатеља, познаника и истомишљеника с којима је размењивао ставове, идеје, недоумице и сумње о своме времену.

Добрица Ћосић је књигу Пријаиељьи, у којој се налази највећи део портрета његових савременика, писаца, сликара, историчара уметности и филозофа, али и познатих друштвених и политичких личности и пријатеља из завичаја, објавио 2005. године. Три године пре те књиге, 2002, објављени су његови Писи, моїа века, у којима се, поред највећег броја портрета који су ушли у књигу Пријашеељи, налазе есејистички или дневнички записи и о оним писцима које је познавао и чије дело је ценио, али с којима се није често сусретао и гајио дугогодишње пријатељство. Зато се у књизи Пријатиељи не налазе текстови о Милошу Црњанском, Десанки Максимовић, Бранку Ћопићу, Васку Попи, Скендеру Куленовићу, Сретену Марићу и Миодрагу Булатовићу, који су, осим оног о Булатовићу, били краћи и углавном писани поводом обележавања годишњица њихове смрти. Такође су изостали и дневнички записи о Андрићу и Крлежи, који немају форму портрета какву има већина осталих текстова у Пријательима.

У књигу Пријашељљи зато су укључени текстови о Ћосићевим пријатељима који нису били писци, али с којима је дугогодишње пријатељство било изузетно важно за њега, јер је испуњавало неке од најзначајнијих година његовог живота и на известан начин усмеравало његову личност према животним активностима и интелектуалним и друштвеним опредељењима која су битно утицала на његов властити стваралачки и интелектуални портрет. То су текстови посвећени шпанском борцу Драгославу Јовановићу Шпанцу, организатору устанка у крушевачком крају против Немаца, Добричином узору трезвеног и толерантног комунисте и у току рата и после њега, затим Госпођи Кристи Ђорђевић, заједно с мужем Ђурицом Ђорђевићем, професором Медицинског факултета у Београду, добротворки српске културе, дворској дами краљице Марије, мецени младих уметника, који су је пред Други светски рат приближили лево оријентисаним интелектуалцима, због несигурног боравка у Београду избеглици у моравски крај током две ратне године, послератној Добричиној добротворки, која је њега и Божицу, „као помајка”, позвала у свој стан у којем су као једна породица живели десет година, где се, како сам Добрица наглашава, „кротио” његов „темперамент и култивисала" његова „партизанштина".

Драгослав Јовановић Шпанац представљен је у Пријатељљима најпре као човек парадокса, који је као син богате сеоске породице неочекивано постао комуниста, али који је „сумњао у сваку величину нашег 
века", како каже аутор његовог портрета, и који је зато јасно видео реалну ситуацију и у току рата и после њега, такође и у време сукоба са Информбироом. Зато је његова личност и у послератном периоду била пример разумног човека, непоколебљивог у идеолошком опредељењу, али свесног реалног стања ствари у своме времену и средини. Таквим особинама изузетно је позитивно утицао на Добрицу и на његов темперамент, а овај је то осећао као велику добит не само за себе него и за послератно време, и зато је знао у најтежем тренутку за Шпанца да му се достојно одужи. На сличан начин је својом благотворном личношћу на Ћосића утицала и Криста Ђорђевић, коју су сви звали Госпођа, једна од најсветлијих личности грађанског Београда пре рата и после њега, која је својим казивањима о међуратним уметницима и писцима усмеравала Ћосића према стваралаштву и култури.

У књизи се налази и текст о Добричином пријатељу и великом поштоваоцу из завичаја Ненаду Неши Михајловићу, најобразованијем сељаку у поморавском крају, чија је библиотека имала неколико хиљада књига, који је присуствовао свим књижевним вечерима организованим у Крушевцу, Трстенику и Врњачкој Бањи. Ту су и два краћа текста, један о француском генералу и пријатељу Србије Пјеру Мари Галоа, који се одлучно супротстављао западноевропској и америчкој пропаганди против српског народа, а други о Јовану Рашковићу, психијатру и вођи Срба у Српској Крајини, с којим је Добрица одржавао интензивно пријатељство све до његове преране смрти. Текстови о Драгославу Јовановићу и Кристи Ђорђевић налазе се на почетку, а текстови о Неши Михајловићу, Јовану Рашковићу и француском генералу на крају књиге Пријайељи, и тиме на известан начин уоквирују њену средишњу садржину посвећену писцима, књижевним и ликовним критичарима и историчарима уметности, као и појединим сликарима, вајарима и филозофима.

Део Пријайеља посвећен писцима почиње текстом о Антонију Исаковићу, с којим се Добрица Ћосић упознао већ на почетку рата, затим о Оскару Давичу, Танасију Младеновићу, Милану Дединцу, Меши Селимовићу, Моми Капору, Петру Џаџићу и Зорану Гавриловићу. О свакој од тих личности, о њиховом стваралачком, психолошком, етичком и интелектуалном портрету, Ћосић је дао веома сликовите, јасне и тачне карактеристике. За Исаковића је записао да се афирмисао као „стамена, разборита, ка слободном и свему напредном отворена и делатна личност”, с којом је још у ноћи, „на трстеничком мосту, августа 1941. године", утемељено вишедеценијско пријатељство. Иако је у том случају, као и у другим, Ћосић избегавао да даје детаљније вредносне оцене о књижевном делу својих пријатеља, ипак се по интонацији његових текстова подразумева да је реч о значајним српским писцима. У појединим случајевима вредносни суд је ипак бивао експлицитније 
изречен, као када је забележио да је Антоније Луле Исаковић, својим „богатим ратничким и животним искуством”, „особеним посматрачким даром”, смислом „за занимљиво фабулирање и метафорисање својих доживљаја”, већ по објављивању приповетке „Кашика” и књиге Велика geщ, доживљаван као „један од најбољих" будућих „приповедача српске књижевности у другој половини двадесетог века" (Ћосић 2005: 43).

О Давичу, свом „књижевном учитељу”, мислио је слично, и то је нагласио већ и насловом свога текста: „Оскар Давичо, велики песник у времену велике обмане", да би нешто доцније записао да је Давичо био „маг српског језика, изумник речи и појмова; творац оригиналне песничке синтаксе и версификације”, који је захваљујући својој „лексичкој имагинацији”, „мислио из језика, новим језиком, метафорама, а не категоријално и когнитивно" (Ћосић 2005: 149). Пријатељство са Давичом било је посебно у многим елементима. Иако је прекинуто због Давичове комунистичке правоверности, Добрица је задржао емотиван однос не само према његовој личности него и према његовом књижевном делу. Тиме је показао да је шири, либералнији и отворенији за другачије ставове и мишљење од многих својих пријатеља, али да их је управо због толерантности и ширине ставова које је заступао могао разумети и када је пријатељство с њима прекидано на дуже време. У Давичовом портрету дате су луцидне опсервације о његовом карактеру, понашању, идеолошким ставовима. На основу њих се може видети да је Ћосић у суштини понудио не само прави психолошки, интелектуални и стваралачки него и етички портрет Давичове личности. А то је учинио и у многим другим случајевима када је писао о пријатељима. И то је, поред изразите наративности којом су остварени готово сви портрети у књизи, једна од њихових најзначајнијих литерарних особина.

Добрица Ћосић је посебно био надахнут када је говорио о оним писцима који су исказивали ширину властите личности и разумевање за ставове другачије од својих. У тексту о песнику Танасију Младеновићу, на пример, он зато с лакоћом запажа да је он „од свих писаца - партизана и револуционара [...] најслободније изражавао своја уверења и осећања. Он је антидогматски и некомформистички дух, отворен за дијалог и сарадњу, срдачан и искрен, увек спреман да подржи младе писце, али и да разуме и помогне старима и онима које смо сматрали буржоаским и реакционарним" (Ћосић 2005: 154), у шта су се могли уверити сви они који су имало познавали Тасу Младеновића. И за разлику од Давича, с којим је пријатељство учвршћено због заједничког опредељења за модернизацију српске књижевности а прекинуто из идеолошких разлога, тачније због политичких размимоилажења, с Тасом Младеновићем је пријатељство у једном времену било прекинуто управо због различитих поетичких страна на којима су се нашли у време подела на такозване 
реалисте и модернисте, да би у доцнијем добу, када су поетичке разлике између некадашњих традиционалиста и модерниста постале много мање и тиме мање важне, било обновљено са истим ранијим интензитетом. Управо такви моменти у животу и пријатељствима Добрице Ћосића показују колико је он као личност био отворен и спреман на сарадњу ради интереса културе и народа којима је служио, колико је изворно био неискључив, пун потребног разумевања за другачије ставове и одлуке. Стога је у закључку портрета Тасе Младеновића могао да устврди да је његов пријатељ био „песник велике наде и слободе, па се згасио у песника меланхолије и зебње; био је песник вере у будућност, па је, поражен стварношћу, постао песник социјалне и духовне резигнације" (Ћосић 2005: 157), и да таквим речима наговести и оцрта и властиту животну, духовну и интелектуалну путању.

Сличан (ауто)поетички и (ауто)етички исказ налази се и у портрету посвећеном Моми Капору. На једном месту, говорећи о Капоровим књигама аутобиографске мотивације, даје се и вредносни суд о једној од њих: „А између тих биографско-монографских и есејистичких књига, једна од најлуциднијих, најзанимљивијих и најлепших књига овог жанра написаних на крају прошлог века - Усйомене јеgноі ирйача, у којој је исказан скоро сав Момо Капор - писац и сликар у једном; хроничар ликовне културе свога доба и биограф својих значајних савременика. То је књига истинита, зналачка, топла, толерантна према различитостима, отворена за ново и сваку стваралачку слободу. Ни у Усйоменама јеgної ирйача Капор никоме и ничему не суди. Са симпатијама и разумевањем приказује и изражава оно највредније и најкарактеристичније о уметницима и амбијенту у коме живе и стварају сликари његовог доба и они које воли" (Ћосић 2005: 282-283). Тим тачним карактеролошким и вредносним опсервацијама он као закључак додаје следећу реченицу: „Момо Капор има редак дар за критичку меру и поштовање сваког ко то заслужује" (Ћосић 2005: 283). Када би се замениле неке чињенице које се односе на Капора, све те речи, све карактеристике о аутору Усйомена јеgног ирйача, могле би се односити и на самог Добрицу Ћосића и на његову књигу Пријайељи. И његова књига је „истинита, зналачка, топла, толерантна према различитостима, отворена за ново и сваку стваралачку слободу". Ни он у њој никоме и ничему не суди и са симпатијама и разумевањем приказује и изражава оно што је највредније и најкарактеристичније за писце, сликаре, филозофе, ликовне уметнике, своје живе или умрле пријатеље. То је такође једна од кључних не само поетичких, књижевних и духовних него и психолошких, етичких и интелектуалних особина саме Добричине личности.

Такав се показивао и када је говорио искључиво о књижевним разлозима, што је веома видно у тексту о Милану Дединцу, у којем нема 
позивања на друштвено и политичко стање времена и средине. Није много био различит ни када се радило о међусобним условљеностима културне, националне, књижевне и друштвене природе, што је посебно наглашено у портрету Меше Селимовића и у дубоко емотивном и искреном, повремено аутокритичком тону којим је он остварен. Једна вредносна опсервација о стилу Меше Селимовића такође је важна за Добричин критеријум у оцени карактеристика писаца о којима говори: на једном месту, упоређујући Андрићев и Мешин стил, он каже да је „Мешина реченица суптилнија и поетскија када се не занесе сувишним описом" (Ћосић 2005: 181). Такве нијансе у оцени може да истакне само писац који осећа ритам свога језика и основне стилске одлике језика других писаца.

У сећањима на толерантну и савесну личност Милана Дединца Добрица Ћосић је исказао и неке своје поетичке ставове о модернизму и постмодернизму, као и поштовање према пријатељима који су му, као Дединац у случају Бајке, као раније Давичо у случају романа Далеко је сунще, или поново Дединац, затим Михиз, Луле Исаковић, Жика Стојковић и Петар Џаџић у случају Деоба, помогли да да коначну верзију романа. Зато су за Ћосићев однос према пријатељима изузетно значајне и непосредне дневнички исписане белешке о току њихове болести, у првом реду Антонија Исаковића, Тасе Младеновића, Меше Селимовића и Михиза, или у Писицма моїа века о последњима данима Иве Андрића, у којима се наговештава дубина и трајност таквих пријатељстава, која се у најоптималнијем облику продужавају и овим портретима.

Иако је Ћосић своје поетичке ставове најчешће исказивао општијим формулацијама, он је и у портретима својих пријатеља писаца и у портретима двојице књижевних критичара, Петра Џаџића и Зорана Гавриловића, спонтано откривао своје поетичка опредељења за модерну књижевност. У портрету Петра Џаџића, „једне од најизразитијих критичарско-есејистичких личности наше савремене књижевности" (Ћосић 2005: 193), доследног заговорника нове књижевности и слободе стваралаштва, посебно у прве две деценије активног бављења текућом критиком, Ћосић на неколико места, уместо појма Свете Лукића „социјалистички естетизам”, с великим разлогом употребљава појам „социјалистички модернизам", који је у једном периоду много чешће коришћен у критичком описивању ликовних уметности, посебно архитектуре, него књижевности. Тиме је он истовремено нагласио значај прве модерне поетичке генерације с либералним ставовима о књижевности и слободи уметности, којој је и сам припадао, и истакао њен утицај на развој и модернизацију српске књижевности после Другог светског рата, а тиме посредно и на модернизацију српског друштва. 
И као што је на једној страни за пријатеља имао Оскара Давича, максималног модернисту, а на другој Тасу Младеновића, који је припадао традиционалнијој песничкој струји, тако је и међу књижевним критичарима на једној, модернистичкој страни имао Петра Џаџића, а на другој Зорана Гавриловића, који је припадао „реалистима”, али који је, будући да је био потомак породице „буржоаског порекла и грађанског угледа", мотивисао Добрицу да се запита како то да такав човек није са модернистима него са њиховим поетичким противницима. Описујући Гавриловићев психолошки и духовни портрет, Ћосић каже: „Никад није било досадно с њим. Увек је имао тему и став. Умна и радознала причалица, умео је да фабулира и драматизује догађај, анегдоту, сећање. Духовит, често патетичан, увек самокритичан и ироничан према себи. Господствен и култивисан у свему што чини и говори; ружио је само политичаре и власт. Господски дух и грађански етос носио је као самосвестан коленовић; опуштен, комотан, лењ; уживалац у свему. Господин, а другарчина; човек за елитни салон и шоферску крчму. Уживао је у поезији, пићу и жени; увек једној. Лепота, духовна и телесна, била је светиња којој је служио" (Ћосић 2005: 204).

Таквим и сличним речима и реченицама и њиховим ритмом Добрица Ћосић је потврђивао једну од такође значајних, крупних, можда и најважнијих естетских и жанровских особина ових портрета. Они су, наиме, не само дискурзивни уметнички текстови са документарном вредношћу, значајем и особинама него и прави уметнички, мемоарски, есејистички и наративни портрети, који се у појединим моментима приближавају правој приповедачкој прози, као што се таквој прози приближавају и многи његови дневнички записи, о којима се такође може говорити из сличне интерпретативне перспективе. Није зато нимало случајно што сам Добрица на почетку портрета посвећеног Антонију Исаковићу каже да „приповест” о њиховом друговању и пријатељству може да започне првим, већ поменутим сусретом на трстеничком мосту на Западној Морави. И у осталим деловима тог и многих других портрета наративне, приповедачке особине текста указују се као његово најупечатљивије књижевно својство.

Састављајући портрете ликовних критичара и сликара, Миће Поповића и групе окупљане у Симиној улици број 9а, међу којима су били Борислав Михајловић Михиз, Војислав Ј. Ђурић, Дејан Медаковић, Живорад Стојковић, Војислав Кораћ, Стојан Суботин, Михаило Ђурић, Петар Омчикус, Бата Михајловић, Павле Ивић и други, затим портрете Миодрага Б. Протића, Лазара Трифуновића и вајара Небојше Митрића, као и филозофа Љубомира Тадића и Михаила Марковића, Ћосић је, с једне стране, говорио о уметницима и њиховом доприносу српској уметности социјалистичког и доцнијег времена, а с друге, о њиховој друштвеној 
делатности и борби за слободу мишљења и демократизацију друштва. У тексту о Мићи Поповићу, најобимнијем у Пријашељьма, налазе се и краћи портрети свих „симиноваца” и опис динамичне интелектуалне атмосфере која је владала међу њеним припадницима, о којој су, поред Добрице, у својим књигама аутобиографске природе врло сликовито и документовано писали и други њени припадници - Борислав Михајловић Михиз, Дејан Медаковић и Жика Стојковић.

У обимном портрету Миће Поповића, чији је почетни и основни предмет претходни Добричин текст припремљен 1974. године за отварање Поповићеве изложбе под називом Призори, која је забрањена, има највише ауторових ставова о тадашњој савременој уметности, о новим тенденцијама у ликовним уметностима, о модернизацији књижевности и демократизацији друштва. Остали делови тог текста су, међутим, испуњени веома сликовитим, динамично описаним, готово оптимално оживљеним портретима других припадника те групе - можда насликовитије портретом Борислава Михајловића Михиза, књижевног критичара који је највише импоновао Ћосићевом стваралачком сензибилитету. И у том портрету, као и у многим другим, његов аутор не заобилази тему демократизације српског друштва и велико разочарање што до тога није дошло и што су сви његови пријатељи с најгорчим осећањима пораза, који је осетио и он сам, са овог света отишли са изгубљеном надом да се то ускоро може променити.

И у текстовима о ликовним критичарима и историчарима уметности, о Миодрагу Б. Протићу, једином пријатељу који га никад није повредио као ни Добрица њега, уметнику који је тежио ка савршенству и теоретичару „стила и форме” коме „стил није манир, него естетизована духовност”, а форма „оно што сваком садржају, ставу и односу даје пун смисао и лепоту" (Ћосић 2005: 168), затим о Лазару Трифуновићу и његовој луцидности, знању, борбености, господству, истрајности у покушајима дедогматизације српске културе и о његовој борби против тоталитарних ставова власти, као и о вајару Небојши Митрићу, уметнику који је „у скулптури, пластици, рељефу, медаљону, створио читав српски пантеон" (Ћосић 2005: 215), и посебно о тајни његове загонетне смрти, Добрица Ћосић даје читаве странице испуњене осећањем пијетета и интелектуалних веза с њиховим личностима, чији карактер и уметничко дело оданим пријатељским речима описује и тумачи.

Два портрета, посвећена двојици филозофа - Љубомиру Тадићу и Михаилу Марковићу, такође откривају неке од кључних особина Добрице Ћосића као писца и јавне личности. Он се у њима представио као аутор коме је и те како стало до слободе интелектуалног и политичког мишљења, до истинске демократизације српског друштва, до оправдане борбе против „титоистичке лажне” и „тоталитарне демократије”. 
Представио се и као борац против двеју крајности у политичком животу земље у последњим деценијама 20. и првој деценији садашњег века - против национализма и против мондијализма, пошто ни један ни други начин решавања националног питања није садржао у себи претпоставку демократичности. (Поред јасних ставова о домаћим политичким и етичким приликама, њему је такође било стало и до интелектуалног и етичког отпора „организованом јавном лагању” западне демократије, како је многе њене активности окарактерисала Хана Арент.) У тексту о Михаилу Марковићу он је, као и у неким ранијим случајевима, говорио и о себи и својој духовној генези. Она се кретала од оптимистичког погледа на свет и стварност, преко скептичког доживљаја властите стварности, до песимистичког доживљаја не само конкретне стварности него и стварности уопште. Песимистичко осећање живота Добрица је спознао као „енергију зла у људима и свету” која је практично неискорењива јер је исконско антрополошко својство човека. У оба текста такође је наглашена Ћосићева способност да на стваралачки, критички и есејистички, али и теоријско-филозофски начин говори о књигама ове двојице филозофа, о њиховим филозофским ставовима, идејама и претпоставкама, о генези њиховог односа према званичној политици државних вођа, о њиховом психолошком и интелектуалном бићу.

Добрица Ћосић је, међутим, 2011. године објавио и књигу под насловом Пријатеељь моїа века, у којој су се нашли сви текстови из књиге Пријайељи, највећи део текстова Писаи, моїа века и известан број сличних написа насталих по објављивању двеју претходних књига. Из Писаиа мої века изостављени су текстови или записи који нису ушли ни у Пријашееље. Остао је, међутим, текст о Сретену Марићу, „Европљанину из Субјела", који претходно није ушао у књигу Пријашељи, а у којем је такође наглашена Ћосићева аутокритичност. (Због неправовременог препознавања уметничких вредности и великог културног доприноса његовог дела српској књижевности, још јача нота аутокритичности приметна је у портрету Меше Селимовића.) Нови текстови у Пријашељьма мог̄a века односе се на Добричино пријатељство са италијанистом и „човеком начела" Никшом Стипчевићем, са Александром Деспићем, научником и једно време председником Српске академије наука и уметности, и са издавачем Владимиром Димитријевићем, оснивачем „Лаж дома” у Лозани. О пријатељима из Добричиног завичаја у књигу је уврштен и портрет сељака и каменоресца Радоја Крстића, Златоустог Радоја, како су га прозвали његови Моравци, кога су убили четници јер је својим говорима за исправну борбу против окупатора и против њих изазвао њихову одмазду. У трећој књизи о некадашњим пријатељима налази се и текст о скојевцу и младом илегалцу Мији Недељковићу, „који је и у слободи шапутао", и који се после рата приклонио совјетској политици, као и о 
светогорском монаху Митрофану Хиландарцу, који је у току рата био на потпуно другој идеолошкој страни од Ћосићеве, али с којим је пријатељство склопљено у току Ћосићевог боравка у Хиландару 1967. године. Тим пријатељством практично је започето, што наговештава овај текст, али никад није довршено Ћосићево мирење са идеолошким противницима из рата.

Портрет монаха Митрофана значајан је за ту књигу и за жанр других Ћосићевих портрета из неколико разлога. Највише због тога што је у њему наративни слој текста, поред критичко-есејистичког и дескриптивног, заузео готово доминантно место. Цео портрет хиландарског монаха доживљава се као приповетка о њему, поготово зато што се у том тексту користе типична средства приповедачке прозе - сликовити описи манастира и његових гостију, приче о појединим монасима, сугестивни дијалози. Између осталих, такав је и дијалог у којем је старешина Хиландара, отац Никанор, током три вечери индиректно одбијао предлог професора Светозара Радојичића да садњу винограда на манастирском земљишту, која је каснила због кишовитог времена и недоласка у Хиландар „геопоноса”, агронома из Кареје, обави Добрица Ћосић, који је у том тренутку, иако комуниста, једини био стручан за виноградарске послове јер је завршио пољопривредну школу. Отац Никанор је то три пута учинио на истоветан начин: „И мој брат је учио пољопривредну школу. Лепа школа, лепа школа... 'Ајте господо да се захвалимо Господу на хлебу и вину, па да идемо на починак" (Ћосић 2011: 410-412). Такође је веома симболичан и обрт на крају те „приповести”, како је жанровски означена, када је исте године, на месту испод маслине под којом је на крају, због продужетка кишовитог времена, Ћосић ипак орезивао саднице и припремао их за садњу, као само чудо, како се то дешавало и у житијима наших светаца, избио извор пијаће воде. Како и остали делови тог портрета обилују типичним наративним моментима, са доста аргумената се може рећи да је то један од најуспелијих и најдинамичнијих портрета које је написао Добрица Ћосић.

Такви су и портрети посвећени Драгославу Јовановићу Шпанцу, Кристи Ђорђевић и Златоустом Радоју, у којима на свакој страници има детаља, призора, ситуација и других стилских елемената који су карактеристични за наративне рукописе. Веома је живо описан долазак младог Добрице Ћосића кроз зимску вејавицу и поред непријатељских стража код Шпанца и разговор са њим, а исто тако и његов повратак у Дренову исте ноћи. Драматично и с пуно саосећања описана је и реакција на вест о хапшењу Драгослава Јовановића Шпанца због Информбироа и Добричин одлазак код Ивана Гошњака због тога. Слична наративна средства употребљена су и у опису веома ризичног боравка Кристе Ђорђевић у Страгарима у току рата, затим одбрана куће Шпанчевог брата Тиле 
Јовановића од четника који су дошли да убију Кристу Ђорђевић, њен неизвесни одлазак у четнички штаб и речита одбрана од њих. Веома драматично и дубоко емотивно описано је и доцније убиство самог Тиле Јовановића, који је, као Тарас Буљба када је пред смрт узвикнуо: „Не умире баба него Тарас Буљба!”, упутио последње речи породици: „Не кукајте! Тилу Јовановића не испраћајте кукњавом!" (Ћосић 2005: 33). Слични наративни призори и обрти дешавају се и у портрету Антонија Исаковића, као што је већ поменути први сусрет на мосту на Морави, или као што је Добричино непоткрепљено охрабривање Исаковићеве мајке да је њен син жив и да је негде у Босни, такође и неочекивани сусрет у ослобођеном Београду Добрице и Антонија после три године, без икакве претходне вести једног о другом. Такав је и цео портрет Златоустог Радоја, нарочито речита полемика између њега и владике Николаја Велимировића и драматичан опис Радојеве смрти саопштен исповешћу његове удовице.

Један од разлога наративне убедљивости и динамичности таквих сцена налази се у чињеници да се ти портрети, осим оног Кристе Ђорђевић, односе на личности из сеоског простора, на њихов боравак у селу и природи и на послове који се обављају у селу. Простор, начин живота у селу, људи који у њему и у раду виде смисао постојања и изворно Ћосићево познавање сеоског живота били су најинспиративнији моменти за настанак таквих сцена и портрета личности које припадају том простору. Тако описани, они су постали примери Ћосићевог наративног стила и његове способности да чињенице биографско-документарне природе претвори у књижевни текст уметничког облика и значења. А он је такве ситуације, као што је рекао за Антонија Исаковића, својим изразитим прозним способностима веома успешно „метафоризовао” у сцене знатне уметничке вредности.

Изразита наративна својства, која се и подразумевају у прози те врсте, поседују и дневнички записи о Андрићу и Крлежи у Писиима моїа века, а посебно их поседује портрет Миодрага Булатовића, који се у целини налази између фикције и стварности, између измишљеног и истинитог, имагинативног и документарног. О томе, поводом описа њиховог првог сусрета, и сам Добрица Ћосић каже: „Тако некако се збио наш први сусрет и почетак друговања и пријатељства; опис је онолико тачан колико су тачни сви описи догађаја у мојим и његовим романима" (Ћосић 2004: 151), чиме је индиректно потврдио могућни и стварни фикцијски и аутофикцијски карактер не само тог него и многих других описа догађаја који су се дешавали током његових пријатељстава са другим српским писцима, уметницима и научницима. То потврђује и Ана Ћосић Вукић у предговорима приређеним књигама свога оца када каже да се Добрица Ћосић у њима није одрекао своје романсијерске вокације. 
Такво поетичко својство његових сећања изразитије је наговештено већ и давнашњим живописним, готово фантазмагоричним неореалистичким описом собе, разговора, спорења и атмосфере колективног живота у Симиној 9а у тексту „Мића Поповић и пријатељи”.

Већина текстова у све три књиге сличног жанровског облика настајала је, како сведочи Ана Ћосић Вукић, из Пищчевих зайиса њеног оца, да би неки од њих за поменуте књиге били допуњени новим детаљима из живота његових пријатеља, или да би књиге произашле из Пишчевих зайиса биле допуњене потпуно новим портретима људи с којима је он одржавао дугогодишње пријатељске везе. Они су, дакле, интегрални део Пишчевих зайиса и њиховог дневничког облика, и у том контексту им је најприродније место. Поготово зато што се о истим пријатељима у дневничким записима и даље налазе делови који нису ушли у поменуте три књиге, али који због везаности за контекст дневника нису могли бити издвојени као самосталне целине, како је то учињено с портретима

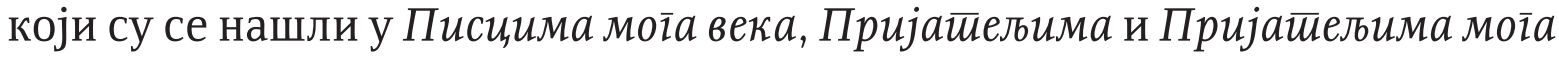
века. Они се у Пишиевим заиисима пре осталог доживљавају као интегрални део целокупног Ћосићевог животног активизма и реакција на свакодневну стварност, као део његове подједнаке посвећености, на једној страни, књижевности, уметности и култури и, на другој, друштвеном и политичком ангажовању, проблематизацији политичке стварности у земљи и покушајима да се она види не само субјективним већ, колико је то било у његовој моћи ствараоца, и објективним погледом. Дневнички

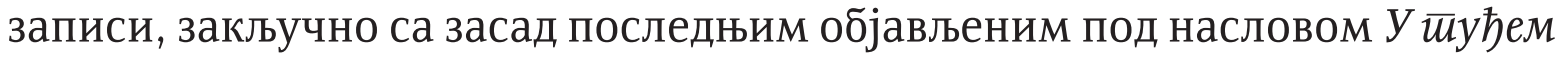
веку, на најнепосреднији књижевни и исповедни начин сведоче о његовој свакодневној уроњености у друштвени и политички живот своје земље и народа, од чијег сиренског зова није могао да се отргне ни до последње године живота. Они истовремено сведоче и о Добричиној изворној везаности за књижевност и културу и за њихов значај не само за његово књижевно дело него и за његову личност и непосредни живот, као и за културу и друштво времена у којем је живео и стварао своје дело.

Све три књиге, међутим, потпуно самостално књижевно и културно значење имају захваљујући издвојеном и тематизованом предмету из дневничких забележака и накнадном уједначавању текстова и њиховом прилагођавању целини рукописа и његовој функцији, за шта велики део заслуга припада и Ани Ћосић Вукић као приређивачу и аутору предговора и поговора за те књиге. Те три књиге имају и неколико заједничких поетичких особина које се добрим делом уклапају у основну Ћосићеву наративну и романсијерску поетику. Једна од најважнијих особина односи се на њихов жанр и изразиту наративност.

Ако ће од српске књижевности друге половине 20. века за будуће читаоце и даље значајни остати поједини романи наших писаца који 
својом садржином, уметничком оствареношћу и интелектуалном постојаношћу сведоче о духу историјске и културне епохе у којој су написани, то ће свакако бити и романи Добрице Ћосића. То ће, међутим, добрим делом бити и његови портрети савременика. Они ће будућим читаоцима бити привлачни не само због богате и илустративне садржине остварене средствима изразитог прозног писца већ и због свеопштег тона разумевања, толерантности, топлине и непосредности, па и идеолошке и етичке доследности помоћу којих су остварени. Ти портрети биће читани и зато што су писани без горчине због престанка појединих дугогодишњих пријатељстава, без претеране субјективности и искључивости тако честих у текстовима сличне врсте, без наметања властитих ауторових погледа и без оштријих речи осуде другачијих ставова његових пријатеља о времену у којем су живели и заједнички деловали као утицајне личности наше културе и књижевности. Они својим тоном, документованом садржином и јасно изнетим ставовима доста мењају и слику о Добрици Ћосићу као јавној и политичкој личности, јер сведоче о његовом много већем степену демократичности, толеранције и разумевања другачијих ставова него што су то његови идеолошки противници били спремни да признају.

Мало која је европска књижевност имала тако значајног писца као

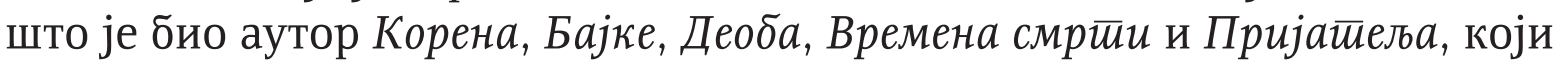
је био аутентични сведок не само књижевне и културне него и читаве друштвене епохе у којој је живео и стварао. Такву улогу у своме времену Добрица Ћосић је на адекватан стваралачки начин потврђивао својим романима, дневничким и публицистичким записима и живописним наративним портретима својих савременика.

\section{ИЗВОРИ И ЛИТЕРАТУРА}

Ћосић, Добрица. Писии моїа века (друго издање). Београд: Завод за уџбенике и наставна средства, 2004. Шт.

Ћосић, Добрица. Пријатељљи. Београд: Политика, Народна књига, 2005. Шт.

Ћосић, Добрица. Пријайељи моїа века. Београд: Службени гласник, 2011. Шт. 
Marko J. Nedić

\title{
THE NARRATIVE PORTRAITS OF CONTEMPORARIES IN DOBRICA ĆOSIĆ'S FRIENDS
}

\begin{abstract}
Summary
The paper critically analyses Dobrica Ćosić's 2005 book Friends, as well as two books similar in genre: the 2002 Authors of My Lifetime and 2011 Friends of My Lifetime, which also contain portraits of his contemporaries. Following a general appraisal of D. Ćosić's literary opus and his contribution to Serbian literature and culture of the second half of the $20^{\text {th }}$ century and the first decade and a half of the $21^{\text {st }}$ century, the opening of the paper presents the genesis of his life which was essential to forming his authorial and public personality. The central part of the paper analyses the key thematic and poetic features of portraits of relevant figures of Serbian culture of the $20^{\text {th }}$ century, among others: Dragoslav Jovanović the Spaniard, Krista Đorđević, Antonije Isaković, Oskar Davičo, Meša Selimović, Tanasije Mladenović, Petar Džadžić, Lazar Trifunović, Ljubomir Tadić, Miodrag Bulatović, Radoje Krstić, Father Metrophanes and the like. With a critical observation that the literary values of these portraits, apart from their documentary, memoir and essayistic layers, can be found in the exceptional narrativity and imagery of the text, as well as in the reviewing of the elementary ethical and creative characteristics of the persons portrayed, the paper lays special emphasis on Dobrica Ćosić's distinct tone of understanding, tolerance and democratic feeling in the dialogue with his contemporaries.
\end{abstract}

